DOI 10.22363/2618-897X-2020-17-2-253-260

Research Article

\title{
Experience of Russian Language Teaching in the Interdom
}

\author{
I.A. Sotova \\ Ivanovo State University \\ Ermaka St., 39, office 420, Ivanovo, Russian Federation \\ E.L. Parfenova \\ International educational center "Interdom" named after E. D. Stasova \\ 21, Sportivnaya St., Ivanovo, Russian Federation
}

The article presents an experience of Russian language teaching in International children's home (Interdom). It describes pedagogical conditions which allows creating of developing environment for the pupils and achieving of high results of Russian language teaching in multilingual audience of pupils. The main difficulties that students encounter in the process of immersion in a new cultural and linguistic atmosphere are analyzed.

Key words: Russian-language teaching in the Interdom, multilingual audience, language environment, Russian-language teaching, individual approach, differentiated teaching of Russian language, extracurricular (out-of-class) work on Russian language

\section{Article history:}

Received: 08.09.2019

Accepted: 30.01.2020

Moderator: U.M. Bakhtikireeva

Conflict of interests: none

\section{For citation:}

Sotova, I.A., and E.L. Parfenova. 2020. "Experience of Russian Language Teaching in the Interdom". Polylinguality and Transcultural Practices, 17 (2), 253-260. DOI 10.22363/2618897X-2020-17-2-253-260

(C) Sotova I.A., Parfenova E.L., 2019

This work is licensed under a Creative Commons Attribution 4.0 International License 


\title{
Опыт преподавания русского языка в Интердоме
}

\author{
И.А. Сотова \\ Ивановский государственный университет \\ Ermaka St., 39, office 420, Ivanovo, Russian Federation \\ Е.Л. Парфенова \\ МЦО «Интердом» имени Е.Д. Стасовой \\ 21, Sportivnaya St., Ivanovo, Russian Federation
}

В статье представлен опыт преподавания русского языка в Международном детском доме (Интердоме). Описаны педагогические условия, позволяющие создать развивающую среду для учеников и добиться высоких результатов обучения русскому языку в многоязычной аудитории. Проанализированы основные трудности, с которыми сталкиваются студенты в процессе погружения в новую для них культурно-языковую атмосферу.

Ключевые слова: русскоязычное обучение в Интердоме, многоязычная аудитория, языковая среда, индивидуальный подход, дифференцированное обучение русскому языку, внеклассная работа по русскому языку.

\section{История статьи:}

Дата поступления в редакцию: 08.09.2019

Дата принятия к печати: 30.01.2020

Модератор: У.М. Бахтикиреева

Конфликт интересов: отсутствует

\section{Для цитирования:}

Сотова И.А., Парфенова Е.Л. Опыт преподавания русского языка в Интердоме // Полилингвиальность и транскультурные практики. 2020. Т. 17. № 2. C. 253-260. DOI $10.22363 / 2618-897 X-2020-17-2-253-260$

On sunny day of July Flowers are everywhere My Russian is so beautiful, Like this summer meadow.

Hadi Chanieva (Ingushetia), Interdom, 2007

\section{Introduction}

In the modern world a problem of foreign language teaching (including Russian as foreign language) to multilingual audience of pupils obtains special topicality. In this context the unique experience of upbringing and teaching of language to foreign children 
in the International children's house (Interdom) is of great pedagogical and methodological interest.

In the current article we will try to characterize the features of Russian language teaching in the Interdom and answer the question: what pedagogical conditions allow teaching of "subtleties of a new language" to the foreign pupils of multilingual class.

\section{Context}

Study analysis is composed of the discussions with a curator of Interdom museum, teachers, administration, and also an analysis of museum materials and publications about the Interdom.

The following study methods were used: analytical and descriptive; pedagogical (conversation, survey).

International children's house (at present moment it's IED «Interdom» named after E.D. Stasova) was built in the town Ivanovo by the initiative of Elena Dmitrievna Stasova, heading Russian department of International organization of help to the revolution fighters, on the means of Ivanovo workers and other donations. In June 1933 it admitted the first children from the age of 3.5 to 16 years (116 people) from the most dangerous trouble spots of the planet. They spoke different languages but were connected by the same disaster: all of them had to abandon home, parents, native land. From the first days in International house were established and maintained laws of multinational family. These children studied at schools of Ivanovo town № 37, 40, 22 etc. together with ordinary soviet children until Interdom opened its own school in 1961.

From the first days of Interdom existence there were carried out lessons of native language (Spanish, Greek, Persian, German, Bulgarian, Portuguese, Chinese, Arabian, Polish, Czech, French, Italian etc.) for the children. These were lessons of native languages and culture taught with big love to the pupils and their far homeland. But it was impossible to find a teacher of native language for the children of all nationalities and then the teacher was replaced by the elder pupil. The teachers painfully recall that there were single cases when a child forgot his native tongue (due to the absence of the native speaker among the teachers and pupils).

Children from more than 80 countries of the world studied in the Interdom. Upon entering the Interdom, children were assigned to different classes based on their knowledge in mathematics. After the preparatory year (sometimes $2-3$ months) of studying Russian language, a resident of Interdom went to the basic school where all subjects were taught in Russian, out-of-class communication was in Russian and the exams were passed on the usual terms with Russian speaking population (it was so during USSR epoch and now as well).

Teachers of Russian language worked in conditions of experiment, developed author's methods of teaching for monolingual and multilingual classes of foreign pupils. Unfortunately, owing to different circumstances, the unique experience of Russianlanguage teaching in the Interdom wasn't described.

That fact that $99 \%$ of them graduated from institutions of higher education testifies to the high level of preparation of Interdom graduates (most often they chose medical, pedagogical or engineering education). They returned to their homeland and achieved success in profession and in life. 
The graduate of the Interdom of 1961 Santiago Alvares recollects his teachers: "I write and think how one should love these unfortunate children, what pedagogue one should be and how one should believe in the work to which he dedicates all his life to create the team of healthy and friendly persons from the children with such a background. We grasped not only subtleties of Russian language but also excellently mastered school knowledge, underwent professional training, haven't forgotten our language and culture and continued to love the native land of our predecessors and managed to become socially responsible persons" [1].

\section{Discussion}

One of the first teachers in the Interdom was assigned Viktor Andreevich Babichev, 1926 year graduate of the department of social and legal protection of minors of Pedagogical institute named after A.I. Herzen. He began his working path under the guidance of Viktor Nikolaevich Soroka-Rosinskiy and could rely on the valuable experience of his tutors. Name of V.A. Babichev is mentioned in memories of Interdom pupil of 1933-1943, Korean Pak Vivian: "I remember well how our mentor, Babichev Viktor Andreevich read us tales by Korolenko - "Blind musician", "Children underground", "A dog of Flanders" etc. $<\ldots>$ There was a big library in the children's house, all of us read much. Children were all-round. Everybody spoke Russian. Children who knew their own language had lessons with pedagogues to maintain the knowledge. Every Sunday we were shown films. We celebrated holidays. New Year was the favorite holiday. When big fir tree was brought, we decorated it together. We organized concerts on our own and also celebrated holiday on 18th of March - "Day of Paris Commune". That day our chiefs came, brought presents, organized tea-parties. We were looking forward to the parents' days, when our parents came. My mother visited me when I was in pre-school division. In 1937 she was already arrested. Of course I knew nothing about it [2. Pp. 297-298]. Among the numerous hobby groups (chorus, music, rhythmics, bench work, sport etc.) Pak Vivian chose rhythmics, mastered elements of dance with a teacher Maria Petrovna Vasina and in 1943 entered (thanks to the mentors of Interdom) dance school of Igor Moiseev having later become a soloist of the ensemble, prominent dancer.

Since 1961 few generations of Russian language teachers have changed each other in the Interdom. These were teachers-enthusiasts, who mastered the methodology of Russian-language teaching in multilingual audience on their own. In the methodology they started from the child and the objective of his upbringing and development, found methodological approaches during the lesson and out-of-class work, developed visual aids and didactic material supplementing a textbook themselves (there were no special textbooks for Interdom children), they implemented elements of differentiated teaching, carried out extracurricular lessons.

We managed to talk with S.M. Sokolova who taught Russian in 1968-1998 in the preparatory division of the Interdom. In the opinion of Svetlana Michailovna, in new language environment the teacher of Russian language and culture as well as teacher of native language became the mediator between the cultures, close person. S.M. Sokolova considers fostering of interest to the subject and lessons as the main objective of a teacher: "I always tried to make interesting lessons to make them love the subject as well as the 
teacher. Every lesson should be creative, give space for the creativity, imagination and fantasy. We played a lot on the lessons. These were the games-competitions, situational and role games. Skills were developed during the games".

There is always time for a feat in the work of modern teacher. Intensive course of Russian language with a teacher I.V. Pikalova allowed 16-years old Syrian boy to enter 8th grade (2015) and prepare for passing of basic school state exam (2017). A student was unsatisfied by the mark "pass" for the obligatory state exam, since he didn't realize that he has mastered Russian language in such a degree that he passed Russian language exam on an equal basis with native speakers - graduates of Russian school. During the preparation of this student, the teacher had to «spend much time on studying of regional geography and history, traditions and culture of Syria». Only when some features of students' behavior became clear.

For example, two junior boys never raised hand and refused to answer having completed the task. It turned out that the etiquette prohibits the junior to answer when the elder one is not ready yet. A sister having done exercises correctly in the copybook, refused to answer out loud, since she was brought up with a belief that in the presence of brothers a girl should keep silence and let her brothers speak. I had to give boys additional tasks and communicate with their sister in another part of the class" [3. P. 258].

Deep comprehension of methodological experience of work with multinational, multilingual audience is reflected in the publications of Interdom teacher, candidate of pedagogic sciences, top-rank teacher Elena Lvovna Parfenova [4-6 etc.], defended a Phd thesis on the problem of differentiated teaching of retelling [7] under the guidance of I.A. Sotova.

When E.L. Parfenova began to work, there were children of 5-7 nationalities on her lessons. Some of them studied in the Interdom from the first grade and spoke Russian well, and some of them began studying Russian from the age of $11-12$ years. In this connection they had to study after the lessons that increased the load on both: students and teacher. Students with bad knowledge of Russian didn't pay efforts during the lessons and responded to teacher's rebukes in the following way: "But you will explain us this after the lessons anyway". So, a young specialist made a conclusion that she should organize a lesson taking into account all students.

Many years past by and the situation repeats: in many schools the bilingual children and non-native speakers attend schools where study those for whom Russian language is native. Many of them know Russian bad: they speak well but write bad or they understand but can't speak. A teacher faces difficult task: how to make a lesson so that all student can be involved in the class activity.

Another difficulty is that in 9th and 11th grades bilingual children pass exams on the usual terms. The structure of exam is such that the graduates should demonstrate not only knowledge of orthography, punctuation but also ability to analyze the given text and write their own text.

Working in class which combines children who are native Russian speakers and those for whom Russian is foreign or not native, the use of the approaches of differentiated teaching becomes necessity.

Differentiated teaching is a work using one program but with different levels of difficulty within the framework of class and lesson system with a purpose of personal development of each pupil. 
Well-known Russian scientist and pedagogue K.D. Ushinskiy recommended to divide classes into groups to give children tasks according to their preparation: «Such division of class into groups, one of which is stronger than another one, is not harmful but even useful if the tutor can give to two groups useful task while working with one more group" [8. P. 99].

More often the class can be divided into three groups: pupils with high academic skills, pupils with average academic skills and pupils with low academic skills.

What criteria are in the base of such division?

Criterion is a quality mastered by the pupils of all groups to a deferent degree. Such criteria can be: volume of knowledge, culture of brainwork, level of cognitive activity, ability to the abstract thinking, ability to analyze and generalize, fatigability from the intellectual activity, level of independence, level of capacity for work (wish and ability to study). Undoubtedly, these criteria are interconnected since the level of self-reliance of the students on the lesson when a teacher organizes intellectual activity depends significantly on the ability of abstract thinking and low workability can bring to naught high intellectual plant of the student.

The students with high educational possibilities have rather wide fund of knowledge, high level of cognitive activity, developed positive qualities of the mind: abstracting, summarizing, analysis, flexibility of mental activity. They fatigue much less from the active intense work then others, have high level of self-reliance and workability. Working with them it's necessary to foresee thorough organization of their academic activity, tasks with high level of difficulty.

Students with average academic abilities have certain volume of knowledge, average level of cognitive activity, they have abilities to abstracting, summarizing and analysis. During the work with pupils with average educational abilities, the main attention should be paid to the development of their cognitive activity, fostering of self-reliance and confidence in their possibilities. It's necessary to always create conditions for the advancement of this group in development.

Pupils with low educational abilities are behind their counterparts in intellectual and speech development. They read bad, can't mark out the main in educational information, have difficulties in operation of comparison, summarizing, systematization, can't hold attention for a long time, have weak knowledge in preliminarily studied material and low level of self-reliance and workability.

Differentiated approach allows us to use abilities of strong students within the class lesson system. Work with them should be carried out not by the way of increase of work volume, but at the expense of the most different tasks: composing of texts of the dictations, composing of cards with tasks on the studied material, composing of summarizing tables for work on the lesson, composing of linguistic fairy tales (miniatures), tasks which broaden the mental outlook of pupils (work with additional literature); check of individual tasks performed by the students with low level; carrying out of duties of a consultant during the group work, work as a teacher (leading of fragments of a lesson).

Child with difficulties in education due to low knowledge of Russian language, should have light load of work. Such pupils need to have supporting schemes, tables. In the class where lessons are carried out, there should be stand with materials for work on the studied topic. On the desks there should be dictionaries and reference books. 
This group of pupils should get more difficult test tasks. For example, of the whole class write a dictation, then the weaker ones can do the tasks on a card.

An ordinary dictation doesn't show real state of orthographic literacy of weak pupils, the therefore a teacher as well as pupils can fall under impression that there no success was achieved but the task on a card allow revealing the real picture of students' achievements. The fact that we offer students such tasks doesn't mean that we don't form skills in orthography. At this stage the biggest difficulties for weak students are finding of orthogram in a text but they do well with choosing of a rule and using of an algorithm which should be applied.

When such a child prepared to perform with spoken response, he/she can be offered a scheme (supporting card) which will help him to structure his reply.

When explain new educational material or during its reinforcement by weak students, they are also offered supporting cards and individual speed of work.

During the studying of new material, weak students need in its gradual make up work, the stronger pupils can work on their own with a textbook and additional literature.

On the stage of reinforcement, the students do different types of tasks, complexity level of which permanently increase. They shouldn't work always with simplified material since their development will slow down.

The role of independent work shouldn't be underestimated. If they are deprived the possibility to practice on their own, they can get used to do everything according to the sample and only with help. But, from another side, they need constant help of a teach more than others.

Differentiated education is possible when the following conditions are met:

- a teacher knows a pupil well, his personal psychological features, his strong and weak sides;

- pupils reached certain level of skills to get knowledge on their own and to control one-self;

- pupils are ready to the joint cooperation (when everyone works on his own it's impossible to carry out differentiated teaching).

Understanding of the essence of differentiated teaching as specially organized activity on studying of one educational content on different level of complexity using different methods of teaching allows pedagogue to improve language, communicative, linguistic competences of the students in their unity and achieve high personal, metasubject and subject results of Russian language teaching in polytechnic class, in multilingual audience of the pupils.

\section{Conclusion}

Interdom experience is, first of all, unique time and unique people. And, of course, unique conditions which allows comparing of the experience of upbringing and teaching of children of the revolution fighters and leaders of antifascist movement with unique experience of Pushkin lyceum.

Success in study of Russian language in Interdom is stipulated by the language immersion experience, individual pedagogical approach to a child, creation of conditions for the development of interests of the students, differentiation of education, powerful organization of pedagogic and out-of-class work. 


\section{References}

1. Al'vares, S. “Kamarada Lagos”. In Rodnoi yazyk. Internatsional'nyi Detskii Dom. Vospominaniya. Ed. Tomas Pamies. (Na pravakh rukopisi). Print. (In Russ.)

2. Son, Zh.G. 2014. "Problemy sotsializatsii semei koreiskikh revolyutsionerov (1920-1930): K istorii voprosa”. In Koreevedenie Kazakhstana. Sb. statei. Almaty: Kazakhskii universitet mezhdunarodnykh otnoshenii i mirovykh yazykov im. Abylai Khana 2: 293-306. Print. (In Russ.)

3. Parfenova, E.L., and I.V. Pikalova. 2017. "Rabota s det'mi-bilingvami i inofonami na urokakh russkogo yazyka (iz opyta raboty Ivanovskogo Interdoma)". In Osvoenie i funktsionirovanie yazyka v situatsii mnogoyazychiya: Materialy ezhegodnoi mezhdunarodnoi nauchnoi konferentsii «Problemy ontolingvistiki 2017». 26-28 iyunya 2017, Sankt-Peterburg/ RGPU im. A. I. Gertsena, Kafedra yazykovogo i literaturnogo obrazovaniya rebenka, Laboratoriya detskoi rechi. Ivanovo: LISTOS. Print. (In Russ.)

4. Parfenova, E.L. 2005. "Vozmozhnosti differentsirovannogo obucheniya v vospitanii interesa $\mathrm{k}$ urokam russkogo yazyka". In Vospitanie uchashchikhsya v protsesse obucheniya russkomu yazyku i kul'ture rechi: Materialy VII Ushakovskikh chtenii, Ivanovo, 4 noyabrya 2004 g. Ivanovo: Ivan. gos. un-t. Print. (In Russ.)

5. Parfenova, E.L. 2005. "Differentsirovannoe obuchenie kak sredstvo vospitaniya interesa k urokam russkogo yazyka”. Russkii yazyk v shkole 3: 33-38.

6. Tomin, V.R. 1980. Dom na Krasnoi Talke: Dokumental'noe povestvovanie. Moskva: Molodaya gvardiya. Print. (In Russ.)

7. Parfenova, E.L. 2010. "Metodika differentsirovannogo obucheniya ustnomu pereskazu uchashchikhsya 5-6 klassov na urokakh russkogo yazyka”. Avtoref. dis. ... kand. ped. nauk. Yaroslavl'. Print. (In Russ.)

8. Ushinskii, K.D. 1968. "Metodika nachal'nogo obucheniya”. In Izbrannye pedagogicheskie proizvedeniya. Moskva: Prosveshchenie. Print. (In Russ.)

\section{Bio Notes:}

Irina A. Sotova is a Doctor of Pedagogical Sciences, Professor, Head of the Department of the Russian Language and Methods of Teaching, Faculty of Philology, Ivanovo State University. E-mail: irina_sota@mail.ru

Elena L. Parfenova candidate of pedagogical sciences, teacher of the Russian language and literature of the highest category of International educational center "Interdom" named after E. D. Stasova (Interdom). E-mail: parfenova_elena0@mail.ru

\section{Сведения об авторах:}

Сотова Ирина Алексеевна - доктор педагогических наук, профессор, заведующий кафедрой русского языка и методики преподавания филологического факультета Ивановского государственного университета. E-mail: irina_sota@mail.ru

Парфенова Елена Львовна - кандидат педагогических наук, учитель русского языка и литературы высшей категории ФГБОУ «МЦО «Интердом» имени Е.Д. Стасовой». Е-mail: parfenova_elena0@mail.ru 